\title{
FIRE AS AN ECOLOGICAL AND SILVICULTURAL FACTOR IN THE PONDEROSA PINE REGION OF THE PACIFIC SLOPE
}

\author{
Harold Weaver ${ }^{1}$ \\ Forest Supervisor, Colville Indian Reservation, Nespelem, Washington, USA
}

\begin{abstract}
This article presents evidence in support of the author's belief that complete prevention of forest fires in the ponderosa pine region of the Pacific Slope ${ }^{1}$ has certain undesirable ecological and silvicultural effects. He emphasizes the fact that conditions are already deplorable and are becoming increasingly serious over large areas, and urges intensive research on the problem.
\end{abstract}

\section{INTRODUCTION}

Wherever man goes in the ponderosa pine region of the Pacific Slope $^{2}$ he sees evidence of past forest fires. The occasional charred remnants of old trunks and stumps, the partially burned snags and windfalls of trees killed by various causes in more recent times, and the charred bark and the basal fire scars or "cat faces" on the trunks of numerous standing live trees are everywhere in evidence. Many apparently unblemished trees when felled are found to have hidden, grown-over scars caused by fires that burned at various times during the earlier life of the tree, some as early as the sapling and pole stages.

The writer believes that these facts indicate clearly that periodic fires, in combination frequently with pine-beetle attacks, and occasionally with other agencies, formerly operated to control the density, age classes, and composition of the ponderosa pine [Pinus ponderosa Lawson and C. Lawson] stands. Undoubtedly the results would often have appeared wasteful and harmful from civilized man's viewpoint. So, in fact, they did appear in many localities subsequent to the settlement of the Pacific
Coast States by the white man. The early forest conservationists consequently concluded that total exclusion of fire was a vitally necessary prerequisite to forest protection and sustained-yield forest management.

As a result of this policy fire has actually been excluded from large areas for from 30 to 40 years. This has brought about changes in ecological conditions which were not fully anticipated, and some of which seem to threaten sound management and protection of ponderosa pine forests. After considerable study, the writer has concluded that progress in converting the virgin forest to a managed one depends on either replacing fire as a natural silvicultural agent or using it as a silvicultural tool. He can see but little evidence of success in solving the first of these problems, and believes that far too little thought and research has been applied to the second. In support of these conclusions he offers the following evidence.

\section{THE RECORD OF THE TREE RINGS}

The precise years during which past fires have occurred can be determined by a study of the rings that show the age of the tree and re-

\footnotetext{
${ }^{1}$ [The author] writes from a background of 17 years' varied experience on the national forests and Indian reservations of the Pacific Coast. This article represents the author's views only and is not to be regarded in any way as an expression of the attitude of the Indian Service [renamed USDI Bureau of Indian Affairs in 1947] on the subject discussed.

${ }^{2}$ California, Oregon, Washington, northern Idaho, and western Montana.
} 
cord the vicissitudes of its life. When fire scars are formed the tree immediately attempts to cover them with new wood, which grows from the living edges of the cambium layer towards the center of the wound. By counting back to where the calluses occur it is possible to determine with considerable accuracy the dates of the fires. Several intensive tree-ring studies have been conducted in the ponderosa pine region. Keen [1937], in his study of climatic cycles in eastern Oregon, found that fires swept the Watkins Butte area of the Deschutes National Forest during the years 1824, 1838, 1843, 1863, 1883, and 1888. The tree rings also indicated similar fire frequencies for other centuries. On another area he found that one of the oldest trees, dating back to the year 1255 A.D., was originally "cat faced" by a fire in 1481. Subsequently, until the tree was cut in 1936, it weathered 25 fires which occurred at approximately 18-year intervals [Keen 1940a].

Show and Kotok [1924] in their study of the role of fire in the California pine forests concluded, from their own observations and from a tree-ring study previously conducted by Dr. J.S. Boyce, that extensive fires had occurred in 25 clearly marked years during the preceding three centuries. They also mentioned Huntington's investigation of the giant sequoias (Sequoia gigantea Lindl. [now Sequoiadendron giganteum \{Lindl.\} J. Buchholz]), which indicates that in the restricted localities of the pine region where these trees now grow fires occurred as far back as the year 245 A.D.

From the evidence presented by the treering studies it is obvious that fires have occurred throughout the ponderosa pine region down through the ages. Over most of the region it is probable that extensive surface fires burned just as frequently as inflammable dead needles, twigs and other debris, and dried grass and brush accumulated in sufficient quantities to support combustion and to carry the fire along the forest floor. Fires then occurred whenever weather conditions were favorable and some natural or human agent caused them to be started. One of the most fruitful sources of fire has always been lightning and it is probable that the Indians caused many fires, either intentionally or by accident.

\section{FIRE AS A CAUSE OF EVEN-AGED GROUPING OF PINES}

The greatest portion of the ponderosa pine forests is characterized by the existence of uneven-aged stands made up of even-aged groups in various stages of maturity. There is abundant evidence that this condition was caused by frequent surface fires operating in conjunction with periodic epidemic attacks of the western pine beetle (Dendroctonus brevicomis Lee.), with occasional attacks of other treekilling insects, and with windthrows.

It is believed that the process was developed and maintained approximately as follows:

1. A single tree or a group of trees, sometimes a very large group, was killed by attacks of the western pine beetle. Similar destruction probably was caused on occasion by the attacks of other insects, or by windthrow, and the surface fires themselves occasionally weakened and destroyed large trees by the repeated burning out of large basal fire scars.

2. In the opening or openings thus created ponderosa pine seedlings germinated. Their subsequent rapid development was encouraged by the comparative freedom from root and crown competition of larger trees.

3. Inevitably another surface fire swept through the forest. The dead snags and windfalls of the large trees that originally occupied the openings were wholly or partially consumed, and many or sometimes all of the seedlings and saplings were destroyed. Usually, however, a number of the dominant, more fortunately situated individuals survived, and 
these, after recovering from the effects of partial defoliation by the fire, put on greatly accelerated growth by reason of the release from competition with their former comrades. If all of the seedlings and saplings in the openings were destroyed the reseeding process was repeated. In some cases the young trees that invariably occupied the openings were subjected to several fires while they were still in the sapling and smallpole stages.

4. After the young trees attained such age and height that they were no longer susceptible to defoliation by surface fires, they were further thinned during the large-pole and "black-jack" stages by the attacks of such insects as the various species of Ips, the mountain pine beetle (Dendroctonus monticolae Hopk. [now Dendroctonus ponderosae Hopkins]), and the western pine beetle. The dead snags resulting from these thinnings were eventually consumed by surface fires.

5. After the trees attained the thrifty mature, mature, and overmature age classes they were in turn susceptible to destruction by the various agents enumerated in paragraph (1). Thus their life cycle was completed and the space that they had occupied was taken over by the new generation of trees.

This cyclic process can be seen in operation in certain parts of the forest at the present time. Single trees and groups of trees are constantly being killed by attacks of the pine beetle. In the openings thus created, there can be observed over a period of a few years the actual germination and subsequent development of the ponderosa pine seedlings. Where recent surface fires of light to moderate intensity have burned there are excellent examples of the thinning process in the patches of reproduction that occupy these openings. Such an example is afforded by the Warm Springs Indian Reservation fire of 1938, on the east slope of the Cascades in central Oregon. On several thousand acres of Tenino Bench the fire did such an excellent job of cleaning up the beetlekilled snags and windfalls and of thinning the adjacent stagnating sapling and pole patches of reproduction that the surviving trees have responded to release from competition and are now making rapid growth.

Throughout the groups of ponderosa pine poles and "black-jack" groups of age classes in excess of 40 or 50 years can be seen the charred remains of the larger trees that originally occupied the site. By taking increment borings or by chopping to determine the age of the young trees, one can find the approximate date at which the larger trees were killed, and by studying the external and hidden scars which most of the young trees bear, one can determine the exact years of the various thinnings by fire.

Everywhere are the groups of thrifty mature, mature, and overmature trees with their tree-ring record of fires of long ago. The evidence is there for those who care to investigate.

\section{INFLUENCE OF FIRE ON EVEN-AGED STANDS}

Extensive even-aged stands of ponderosa pine can probably be accounted for by the past occurrence of severe crown fires, by severe epidemics of tree-killing insects such as the defoliating white-pine butterfly (Neophasia menapia Felder), or by the occurrence of extensive windthrows caused by cyclonic winds. Subsequent to the insect killings or the windthrows, fires of great intensity often occurred.

In the early 1900s the white-pine butterfly killed a major portion of the ponderosa pine stand on several townships of the Yakima Indian Reservation on the east slope of the Cascades in southern Washington. A dense even- 
aged stand of ponderosa pine reproduction now occupies this area. Because of its existence and the dead windfall and snag remains of the original stand, the fire hazard is tremendously increased. Thanks to the protective efforts of the foresters, however, fires have not thus far entered the picture. This stand is now badly stagnated and thinning to get released growth presents a difficult management problem. (Figures 1, 2, and 3.)

\section{BURNS AT HIGHER ALTITUDES}

At the higher elevations in the ponderosa pine region, particularly in the Upper Transition and Lower Canadian zones, where moister conditions usually prevail and the dry seasons are much shorter, fires naturally occurred at less frequent intervals. When fires did occur, however, they usually caused great destruction because of the low-branching growth habits, abundant reproduction, and great amounts of accumulated inflammable debris characteristic of the fir or fir-larch forests that form the climax type on such sites. Lodgepole-pine [Pinus contorta Douglas ex Loudon] trees also have always been very susceptible to fire because of their thin bark. Also where such stands have previously been decimated by severe epidemics of the mountain pine beetle, crown fires of extreme intensity have usually developed.

Most of the burns of the Upper Transition and Lower Canadian zones have been restocked to even-aged pure and mixed stands of lodgepole, ponderosa, and western white pine [Pinus monticola Douglas ex D. Don] and occasionally, in Washington, Idaho, and Montana, to western larch [Larix occidentalis Nutt.] and Douglas fir [Pseudotsuga menziesii (Mirb.) Franco].

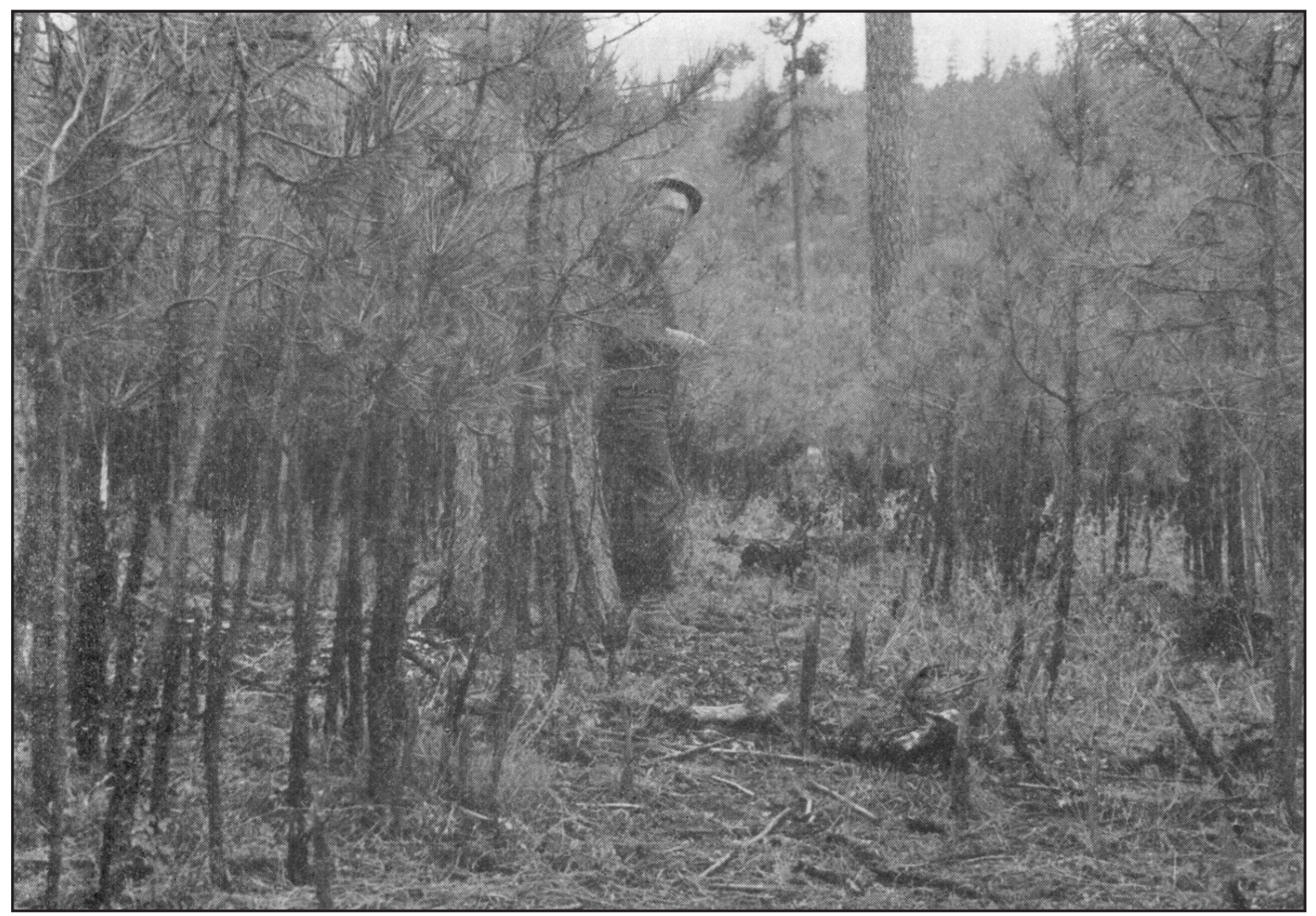

Figure 1. This stagnating stand of 37-year-old reproduction near Nespelem. Washington, is typical of the dense even-aged stands of ponderosa pine that have developed since the advent of total fire exclusion. 


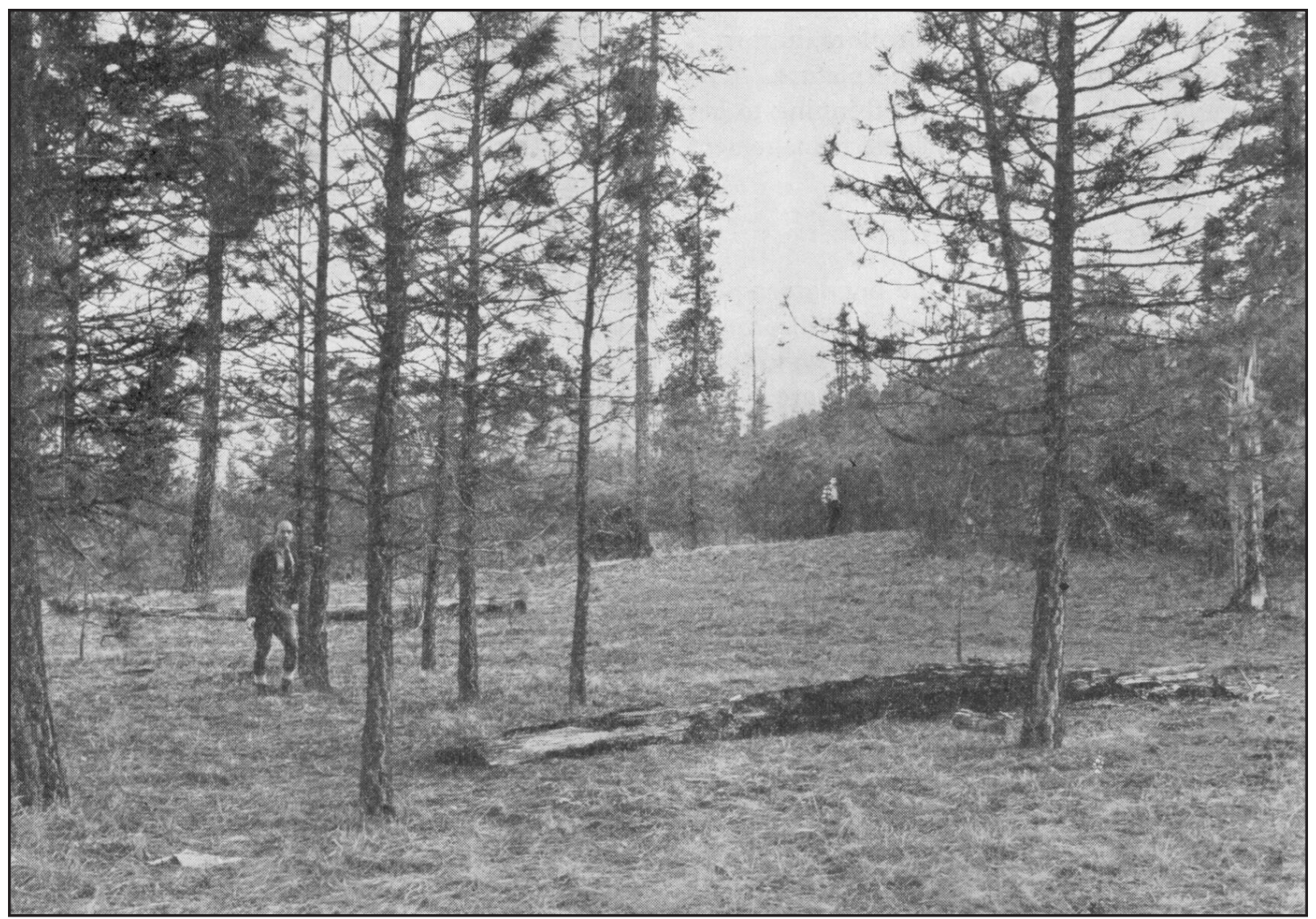

Figure 2. A portion of the stand shown in Figure 1 as it appeared in 1941 after being thinned by a surface fire in 1914. In the background and to the right can be seen the edge of the stagnating thicket, along and outside of the 1914 fire line.

\section{IMPORTANCE OF FIRE AS AN ECOLOGICAL FACTOR}

Past history indicates clearly that fire has always been an extremely important ecological factor in the ponderosa pine region. Dr. Willis Linn Jepson [1923], in his Trees of California, makes the following statements:

The Sierra Nevada forest, as the white man found it, was clearly the result of periodic or irregular firing continued over many thousands of years. As a result the Sierran forest shows marked reactions to millennial fire conditions. Three observations illustrate this statement. First of all, the forest stands in this belt occur where from the nature of the topography the fire ravage would be expected to be less severe; secondly, the individual trees are extremely well-spaced and commonly form a very open forest, the degree of openness often being in direct ratio to the age of the stand; thirdly, the trees as a whole, without regard to specific relationship, exhibit trunk bark of such unusual thickness and often of such non-inflammable character that it may be taken as evidence of protection to the tree if not of marked adaption to fire ravage.

Dr. Jepson then states that the most abundant tree in the Sierran forest is the yellow (ponderosa) pine which has fire-resistant bark 2 to 5 inches thick. In discussing the Sierran forest he says, "Indeed the main silvical fea- 


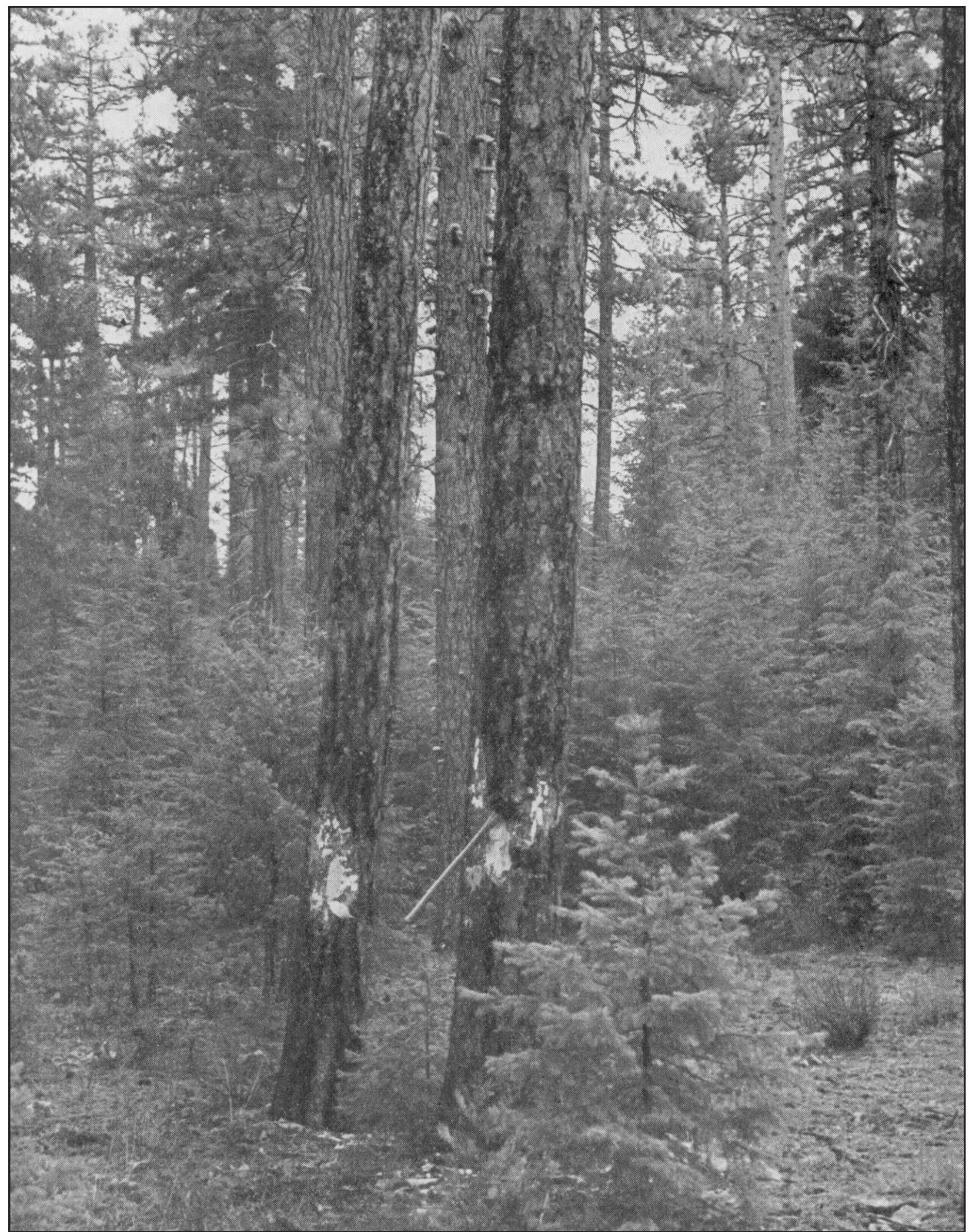

Figure 3. This stand near Badger Creek, Warm Springs Indian Reservation, Oregon, is typical of vast areas of the ponderosa pine region where, as a result of total fire exclusion, dense even-aged stands of Douglas-fir reproduction are monopolizing the ground under the mature ponderosa pines. 
tures, that is, density, reproductive power and dominance of types, are in great part expressions of the periodic fire status."

Although the fact that fire has always been an important ecological factor is recognized to a certain extent by most foresters, many of them disregard or minimize the possibility of utilizing fire as a silvicultural agent in the management of ponderosa pine forests. They refer to the past fire history of the stand as "the process of attrition" and assume that the magnificent, open pine forests found by the first white man on entering this region were but understocked, patchy stands, "worn down by the attrition of repeated light fires." In the dense stands of reproduction that have come in as a "veritable blanket" under the mature stands since the advent of fire protection, they see proof of this interpretation. Show and Kotok [1924], for example, state that, "This remarkable change is in itself proof that the virgin forest as we find it does not represent the productive capacity of the land, for if an area of ground is fully occupied by a mature crop of timber the young individuals cannot obtain a foothold because the available moisture and light are fully utilized."

From its very inception, the policy making and the administrative and investigative phases of our fire protection program have been largely guided by foresters of the school of thought which favors total exclusion of fire. As a result over the greatest portion of the ponderosa pine region where we have had organized protection, fire has actually been excluded from large areas for from 30 to 40 years. Some of the resulting conditions and changes that the writer considers most significant are as follows:

1. Dense even-aged stands of ponderosa pine reproduction have developed. Where these stands have established themselves on the better sites, in the natural openings constantly being created in the virgin forest and on the clear-cut and selectively cut lands, they appear to be making excellent growth. Over the greatest portion of the region, however, especially where they comprise "veritable blankets" under the mature trees, they are making exceedingly poor growth. Meyer [1934] in his study of growth in selectively cut ponderosa pine forests makes the following statements:

The slowness with which the reproduction stand develops is one of the most discouraging phases of the management of selectively cut ponderosa pine forests in the Pacific Northwest. ... Overstocking and clumpiness may be the principal causes; the oftmentioned poor growth conditions of the last decade or two may be also a factor. On the average, the reproduction stand can be counted upon only to produce about 10 per cent of the normal yields for site index 80. This situation is deplorable. If stagnation is allowed to persist it will imperil the cuts at the end of the second and subsequent cutting cycles.

2. Enormous areas are growing up to dense, even-aged stands of white-fir, Douglasfir, and incense-cedar reproduction under the merchantable ponderosa pines. These species are very susceptible to killing by fire, which has largely excluded them from such stands in the past. When fire is kept out, however, they come in under the dense shade of the larger trees, and under such conditions the less tolerant ponderosa pine seedlings have no chance to compete.

3. For the past 20 years epidemics of the western pine beetle have killed and are continuing to kill billions of board feet of ponderosa pine worth many millions 
of dollars. These epidemics are apparently more severe than those that formerly occurred in the ponderosa pine region. In the past two decades, in the states of Oregon and Washington alone, the beetles have killed 15920000000 board feet of merchantable ponderosa pine conservatively valued at $\$ 40000000$ [Keen 1940b]. Foresters and entomologists believe that these epidemics resulted principally from the severe drought conditions that prevailed generally over the period. It has been found that during periods of moisture deficiency, competition between trees is greatly increased and losses mount rapidly. It is believed that the dense stagnating stands of reproduction that have developed on vast areas have aggravated the beetle losses tremendously as a result of their competition with the larger trees for the limited soil moisture. (Figure 4.)

4. Because of these ecological changes, which are continuing to take place, the fire hazard has increased tremendously. Fires, when they do occur, are exceedingly hot and destructive and are turning extensive areas of forest into brush fields.

\section{CONCLUSION}

It is obvious that the present policy of attempting complete protection of ponderosa

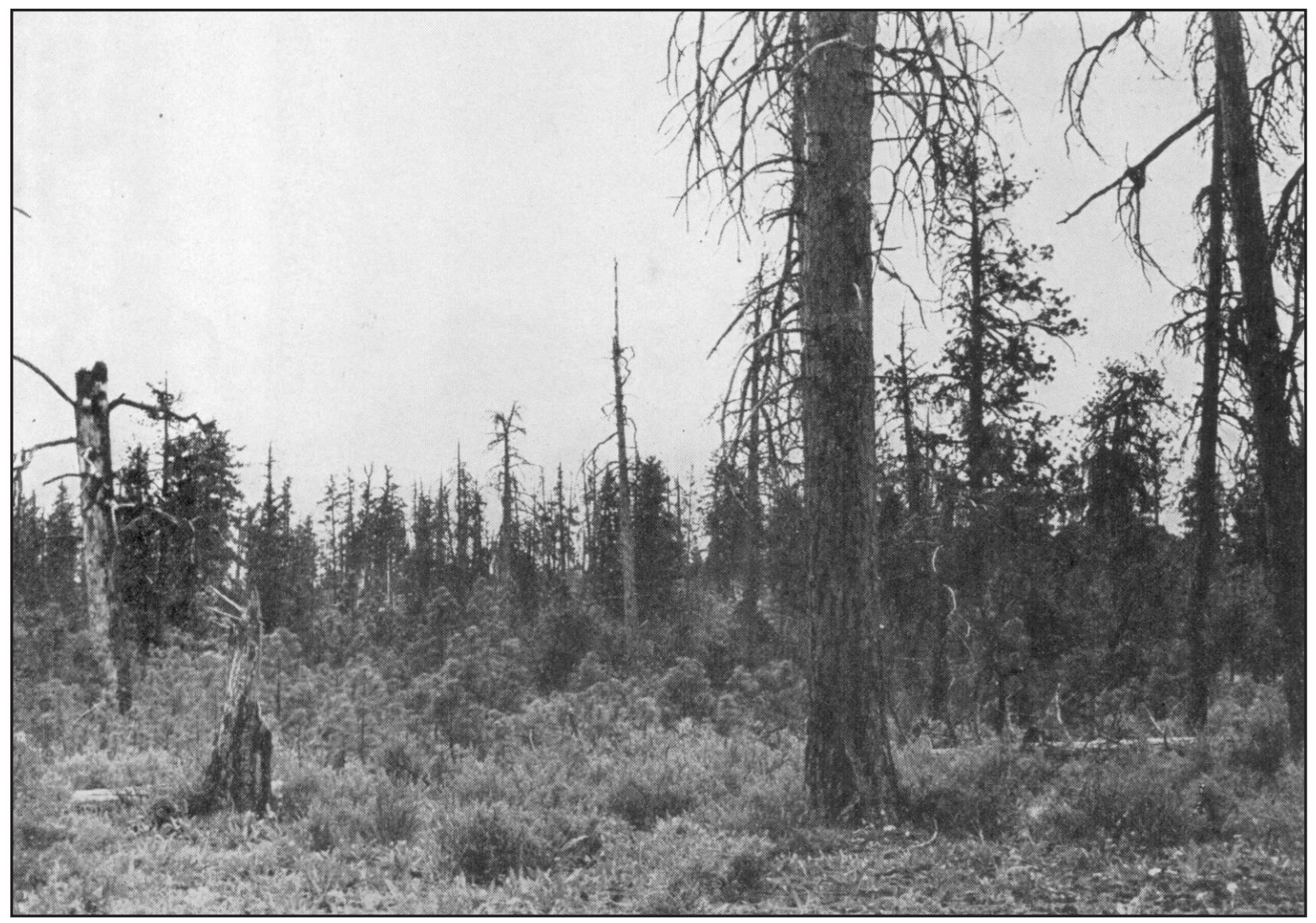

Figure 4. This stand on Metolius Bench, Warm Springs Indian Reservation, Oregon, is typical of the beetle-riddled forests on hundreds of thousands of acres in Oregon and northern California. Because of the immense number of dead resinous snags and the stagnating lands of reproduction, the fire hazard has increased tremendously. 
pine stands from fire raises several very important problems. How, for instance, will the composition of the reproduction be controlled? If ponderosa pine is desired on vast areas how, unless fire is employed, can other species such as white fir be prevented from monopolizing the ground? On the other hand, if it is decided to permit such species as white fir to come in under mature ponderosa pine, how much of the public's money are foresters justified in spending in trying to keep fire out? Even with unlimited funds, personnel, and equipment, can they give reasonable assurance that they can continue to keep such extremely hazardous stands from burning up? If they feel reasonably sure of this, can they then give assurance that the timber products of such stands will be more valuable than those that might otherwise be derived from ponderosa pine and will in addition justify the high protection costs?

How will the density of the reproduction and pole stands on other vast areas be controlled unless fire is employed as a thinning agent? Except in stands on unusually good sites and favored locations, artificial thinning operations are so expensive as to be entirely unfeasible. The present stagnated stands have obviously resulted from total fire exclusion. It is well to remember that "rain-forest" conditions do not prevail in the ponderosa pine region and that root competition for the available soil moisture is probably, therefore, a more immediately critical factor than competition for light. The ponderosa pine region is not capable of sustaining a dense forest like the Doug- las-fir and redwood (Sequoia sempervirens [Lamb. ex D. Don] Endl.) regions.

How will the terrific pine beetle epidemics that are continuing to ravage large portions of the ponderosa pine region be stopped? Present methods of artificial control, even the promising method recently developed of removing the most susceptible trees in light selection cuttings, are but expedients of temporary benefit. The probable aggravation of these epidemics, caused by the reduced vigor of the trees due to excessive root competition for limited soil moisture, has already been mentioned.

It is the writer's opinion that investigative work to solve these problems should be undertaken immediately. He believes that unless the stagnating stands of reproduction can be thinned and the terrific destruction by pine beetles can be checked the success of sustained-yield forest management in the ponderosa pine region is seriously threatened. The present deplorable and increasingly critical conditions in vast areas of the region are proof that foresters have not solved the silvicultural problems of ponderosa pine, and to continue present policies will further aggravate an already serious situation. These conclusions are the result of some seventeen years of close association with the ponderosa pine forests, during which time ample opportunity has been afforded to observe the developments discussed. How to correct this increasingly serious condition constitutes a growing challenge to the professional forester and is a job worthy of the best minds in forest research.

\section{LITERATURE CITED}

Jepson, W.L. 1923. The trees of California. University of California Press, Berkeley, USA.

Keen, F.P. 1937. Climatic cycles in eastern Oregon as indicated by tree rings. Monthly Weather Review 65: 175-188.

Keen, F.P. 1940a. Longevity of ponderosa pine. Journal of Forestry 38: 597-598.

Keen, F.P. 1940b. Western Forestry and Conservation Association. Page 97 in: Proceedings from the Forest Policy Conference. Portland, Oregon, USA.

Meyer, W.H. 1934. Growth in selectively cut ponderosa pine forests of the Pacific Northwest. US Department of Agriculture Technical Bulletin 407, Washington, D.C., USA. 
Show, S.B, and E.I. Kotok. 1924. The role of fire in the California pine forests. US Department of Agriculture Department Bulletin 1294, Washington, D.C., USA.

\section{COMMENTS}

Mr. Weaver offers some challenges to firecontrol policies of public agencies that deserve careful consideration. At the request of the editor I am glad to give a very brief size-up of the issues he raises, from the point of view only of a member of the S.A.F. [Society of American Foresters] with the particular background of experience I happen to possess, and with the hope of evoking further discussion.

Undoubtedly Weaver lays himself open to the criticism of taking in too much territory in many of his assertions, which are based on his own observations and applied to ponderosa pine in California, Oregon, Washington, northern Idaho, and western Montana. But any comments in this respect will be left to other foresters in that territory.

At the start it is fair to say that ponderosa pine silviculture everywhere is still in the process of evolution. If any timber management men believe to the contrary, that it is already settled and can now be applied as an exact science, they should come forward with supporting evidence.

Certainly it should be generally recognized that where ponderosa pine is not the climax type, a policy of complete exclusion of fire accompanied by selection cutting will eventually result in a stand in which more tolerant species are apt to predominate. This seems to be one of the main issues in Weaver's argument. Though it is not new, it deserves reemphasis. It should, however, be recognized that the change in composition may or may not be undesirable, depending on the value of the alternate species and the confidence with which the silviculturist can predict the market demand a hundred years hence.

His second point is that proper thinning in ponderosa pine can be accomplished by burning and was nature's method. In California much research has been conducted on how to get ponderosa pine reproduction rather than how to get rid of it. Overstocked and stagnating stands seem so far from typical of the region for which he speaks that one wonders if $\mathrm{Mr}$. Weaver is not generalizing too much from a single area. A partial kill of a stand of reproduction can occur only with a surface fire of very low intensity in thin duff. It is almost impossible for a fire-control man to visualize such a fire over any sizable area in a stagnated stand of ponderosa pine reproduction. Typically, if the fire will run at all in such fuel it will crown it out clean. Only along the fringe of the burn will there be a partial kill of the sort illustrated by Weaver.

At best a stand of pine reproduction is a hazardous fuel until it begins to clean from underneath and the crowns get out of reach of a surface fire. Extra protection can well be justified to carry it through this critical period. Even where thinning by the axe can be accomplished, the temporary fuel hazard is not decreased unless all slash can be disposed of. A really stagnated stand does not occur on good sites, but presents a problem area where it does occur. The question is whether the remnants left after burning such a stand will be of more value than the original stagnated stand if left to struggle out of its own deadlock. But the question is not highly significant unless considerable areas and timber-producing capacities are involved.

A third point is whether a stand of reproduction, particularly of other species, may give serious ground competition to the mature overstory of pines on sites where competition for soil moisture rather than light may be the limiting factor. Presumably Keen has some evidence that mature trees become more susceptible to beetle attack with heavy competition from below of this kind. This is an interesting possibility that well justifies careful follow-up. 
In conclusion, a word on the general philosophy that I believe has controlled to date. To serve society, the forester must substitute harvesting by logging for nature's method of harvesting by bark beetles and fire. To do that he must intervene in the old natural cycle. The first urgent step was to control fire and insects. With nature's harvest reduced, there is an opportunity for system in the second step, which is management of the forest by methods of cutting. With both under full control, which has not yet been attained, there will be much room for refinement of method.

Fire as a silvicultural tool has been used in slash disposal. Can it, as Weaver contends, be introduced at other stages with benefit rather than damage to the stand? The effects of fire are conditioned by so many ifs involving age, stocking, ground cover, and burning conditions that one need have no horror of using fire to attain silvicultural ends to agree strongly with his conclusion that the answer requires considerable prior research.

\section{-Arthur A. Brown}

Reprinted with permission from Weaver, $H$. 1943. Fire as an ecological and silvicultural factor in the ponderosa pine region of the $\mathrm{Pa}$ cific Slope. Journal of Forestry 41(1): 7-15. Copyright 1943 by the Society of American Foresters. 